\title{
Improving the ammonia sensing of reduced graphene oxide film by using metal nano-materials
}

- Huynh Tran My Hoa

- Hoang Thi Thu

- Nguyen Thi Phuong Thanh

- Nguyen Ngoc Tham

- Bui Thi Tuyet Nhung

- On Thi Thanh Trang

- Tran Quang Trung University of Science, VNU-HCM

- Lam Minh Long

HCM City Vocational of College

University of Engineering and Technology, VNU-HN

(Received on December $04^{\text {th }} 2014$, accepted on September $23^{\text {rd }} 2015$ )

\section{ABSTRACT}

Gas sensing is one of the most promising applications for reduced graphene oxide (rGO). High surface-to-volume ratio in conjunction with remaining reactive oxygen functional groups translates into sensitivity to molecular on the rGO surface. The response of the rGO based devices can be further improved by functionalizing its surface with metal nano-materials. In this paper, we report the ammonia $\left(\mathrm{NH}_{3}\right)$ sensing behavior of rGO based sensors functionalized with nano-structured metal: silver (Ag) or platinum (Pt) or gold (Au) in air at room temperature and atmospheric pressure. The gas response is detected by the monitoring changes in electrical resistance of the rGO/metal hybrids due to $\mathrm{NH}_{3}$ gas adsorption. Compared to bare rGO, significantly improved $\mathrm{NH}_{3}$ sensitivity is observed with the addition of nanostructured metals. These materials are applied to play the small bridges role connecting many graphene islands together to improve electrical conduction of hybrids while maintaining the inherent advantage of rGO for $\mathrm{NH}_{3}$ gas sensitivity.

Key word: reduced graphene oxide, silver nanowires, polyol method, $\mathrm{NH}_{3}$ gas sensing.

\section{INTRODUCTION}

Recent studies revealed that the reduced graphene oxide or chemically modified graphene (rGO) can be served as high performance molecular sensors because rGO contains a range of reactive oxygen functional groups. Many groups extensively studied molecular adsorption on rGO and proposed that the active defective

sites provided by the residual oxygen or hydroxyl functional groups during the reduction of GO may improve the interaction of adsorbate and GO, thereby enhancing the sensor response [1-3]. However, most of the rGO sensors were recovered very slowly after sensing $\mathrm{NH}_{3}$ at room temperature. This shortcoming must be overcome

\section{Trang 72}


to apply rGO to $\mathrm{NH}_{3}$ detection at RT. One of methods to improve the recovery of these rGO based sensors was the decoration of nanomaterials on the surface of rGO $[4,5]$.

For the synthesis of metal nanostructures, various methods have been successfully developed. Up to now, the polyol method has become widely used by many research groups because of its advantages such as cost, yield, and simplicity [6-9].

In this study, we report on the synthesis of $\mathrm{rGO} /$ metal hybrid nano-structures by using chemical method for making rGO thin films and polyol process for synthesis metal nano-materials ( $\mathrm{Ag}, \mathrm{Au}$ and $\mathrm{Pt}$ ) and then these hybrids are applied in the $\mathrm{NH}_{3}$ gas sensors.

\section{METHODS}

Synthesis of reduced graphene oxide (rGO) and metal nano-materials

Synthesis of $r G O$. Graphite was oxidated to graphene oxide (GO) by using the mixture of $\mathrm{KMnO}_{4} / \mathrm{NaNO}_{3} / \mathrm{H}_{2} \mathrm{SO}_{4}$ (modified Hummers method). This GO solution was spin-coated directly onto quartz substrate. The GO thin films were subsequently reduced to $\mathrm{rGO}$ using chemical agent (hydrazine) and heating $\left(250{ }^{\circ} \mathrm{C}\right)$. More details about the synthesis of rGO was presented in our previous papers $[10,11]$.

Synthesis of metal nano-materials. The Ag, $\mathrm{Au}$ and $\mathrm{Pt}$ nano-materials were synthesized through polyol method. This polyol process is based on the reduction of an inorganic salt by a polyol at an elevated temperature and a surfactant is used to prevent the agglomeration of the colloidal particles. In our experiment, $\mathrm{AgNO}_{3}$, $\mathrm{HAuCl}_{4}$ and $\mathrm{H}_{2} \mathrm{PtCl}_{6}$ were used as $\mathrm{Ag}^{+}, \mathrm{Au}^{3+}$ and $\mathrm{Pt}^{4+}$ source, respectively. Ethylene glycol (EG) was used as both solvent and reducing agent for reduction of $\mathrm{Ag}^{+} / \mathrm{Pt}^{4+}$ ions to $\mathrm{Ag}^{0} / \mathrm{Pt}^{0}$ atoms and polyvinyl pyrrolidone (PVP) and $\mathrm{NaCl}$ were used as stabilizing agents. Small gold nanoparticles were prepared by the reduction of $\mathrm{Au}^{3+}$ ions with sodium borohydride/ascorbic acid in the presence of a stabilizing agent (trisodium citrate or CTAB) [7-9].

\section{Preparation of gas sensing devices and measurement system}

After the rGO thin films were formed, two silver planar electrode arrays were deposited on the rGO films using thermal evaporation method with $6 \mathrm{~mm}$ distance between them. Finally, we used spray-coating method to disperse metal nano-materials on rGO surface area between two electrodes to complete our gas-sensing devices which is ready for $\mathrm{NH}_{3}$ sensing signal measurement. More details about the preparation of gas sensing devices were presented in our previous paper [12].

Five chemiresistor devices with different sensing layers including $\mathrm{rGO}, \mathrm{rGO} / \mathrm{AgNPs}$ (NPs nanoparticles), rGO/AuNPs, rGO/PtNPs and $\mathrm{rGO} / \mathrm{AgNWs}$ (NWs - nanowires) were fabricated under identical conditions in order to compare their sensitivities toward $\mathrm{NH}_{3}$ gas at room temperature. 


\section{RESULTS AND DISCUSSION}

Fig.1 shows the Energy-dispersive X-ray Spectroscopy (EDS) spectra of the Ag, Au and $\mathrm{Pt}$ thin films, spraying of their solutions onto quartz substrates, which contain strong peaks for

elemental $\mathrm{Ag}, \mathrm{Au}$ and $\mathrm{Pt}$ suggesting the formation of $\mathrm{Ag}$, Au and Pt nano-materials in synthesis processes.

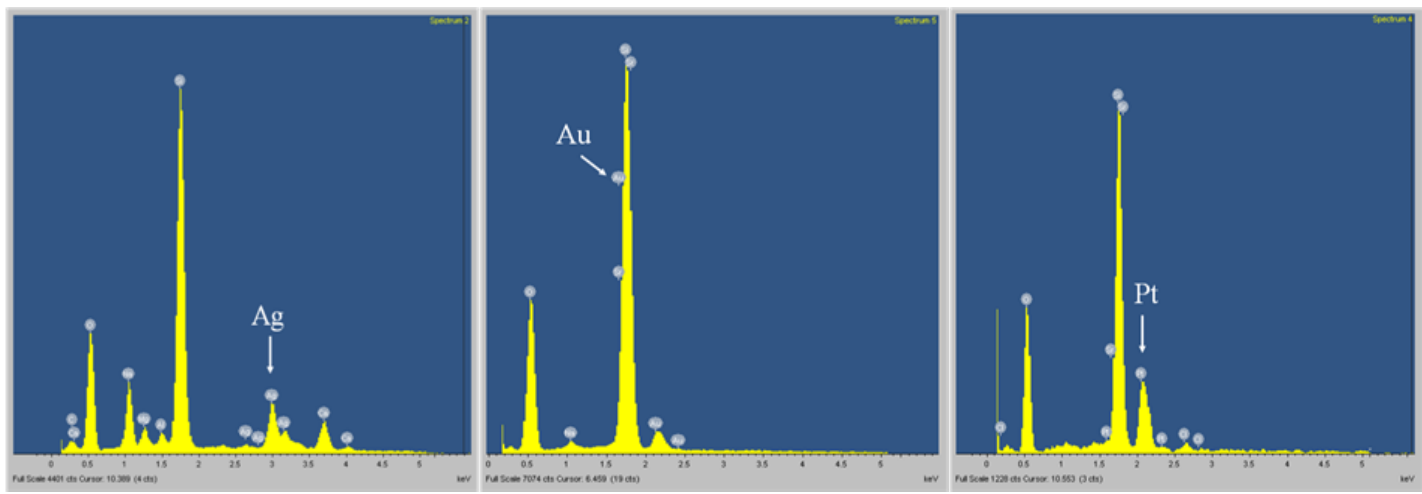

Fig. 1. Energy-dispersive X-ray Spectroscopy - EDS of the Ag, Au and Pt nanomaterials
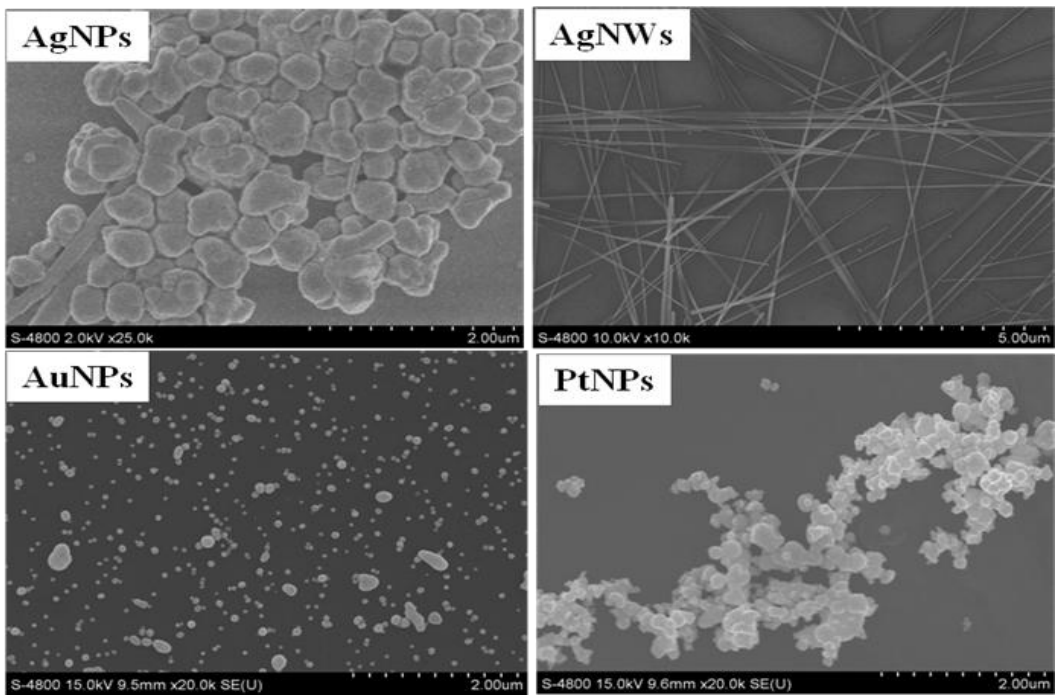

Fig. 2. SEM images of metal nanomaterials: AgNPs - Silver nanoparticles; AgNWs - Silver nanowires; AuNPs Gold nanoparticles; and PtNPs - Platinum nanoparticles

Then, in order to obtain the general view and the detailed structural information of the metal nano-materials, the SEM observation of the materials, synthesized by using of polyol method, are shown. According to Fig. 2, the observation indicates that the synthesized product from $\mathrm{AgNO}_{3}$ precursor includes AgNPs - Silver nanoparticles (diameter $~ 400 \mathrm{~nm}$ ) and AgNWs -
Silver nanowires (length $>5 \mu \mathrm{m}$ ). While the synthesized product with $\mathrm{HAuCl}_{4}$ and $\mathrm{H}_{2} \mathrm{PtCl}_{6}$ precursors is only AuNPs - Gold nanoparticles (diameter $100 \mathrm{~nm}$ ) and PtNPs - Platinum nanoparticles (diameter $\sim 200 \mathrm{~nm}$ ), respectively. In this work, the conditions for formation of gold nanowires and platinum nanowires are not determined.

\section{Trang 74}



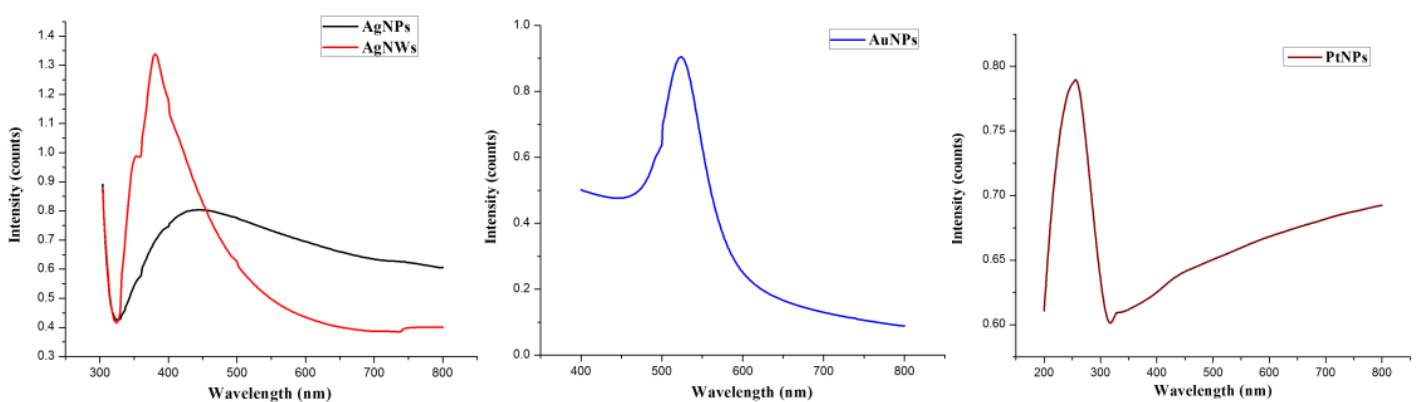

Fig. 3. UV-vis spectra of metal nanomaterials: A) AgNPs and AgNWs; B) AuNPs and C) PtNPs

Continuously, Fig. 3 shows the UV-visible absorption spectra of $\mathrm{Ag}, \mathrm{Au}$ and $\mathrm{Pt}$ colloid solution products. These spectra fortify the formation of metal nano-materials in our experiment with the appearance of their typical peaks. The large peak around $445 \mathrm{~nm}$ suggests that the final product is AgNPs with a large range of different diameters while a peak at $\sim 380 \mathrm{~nm}$ and the shoulder around $\sim 350 \mathrm{~nm}$ indicate that the main product is AgNWs in solution (Fig $3 \mathrm{~A}$ ) [13-15]. Besides, the peaks at $\sim 520 \mathrm{~nm}$ and $\sim 250$ $\mathrm{nm}$ show the presence of AuNPs and PtNPs in final products, respectively $[9,16]$. The nanomaterials solutions are ready for combine with rGO and complete the gas sensors.

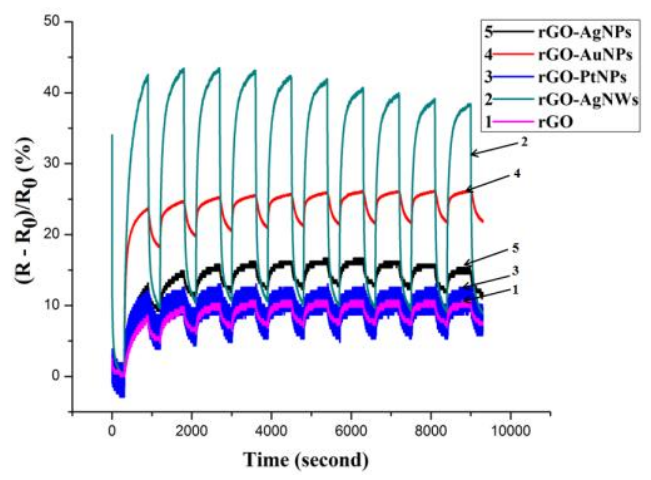

Fig. 4. Response to $\mathrm{NH}_{3}$ gas of five sensing devices are made from the different materials: bare rGO and rGOAgNPs, rGO-AgNWs, rGO-AuNPs, rGO-PtNPs hybrids

Finally, we investigate the sensitivity ability $\mathrm{NH}_{3}$ of bare rGO material and its hybrids with these metal nano-materials. The experimental processes are performed in the same condition (room temperature and atmospheric pressure). The data in Fig. 4 show that the sensitivity ability of original rGO material is improved significantly by nanomaterials. In comparison with the sensitivity of bare rGO material (10\%), the sensitivity of the rGO-AgNPs, rGO-AuNPs and rGO-PtNPs hybrids increases $15 \%, 25 \%$ and $12 \%$, respectively, although the recovery of these sensors remain uncompleted. Particularly, the combination of $\mathrm{rGO}$ and AgNWs with the length more than $5 \mu \mathrm{m}$ affords not only to improve $\mathrm{NH}_{3}$ gas sensitivity $(40 \%)$ but also nearly complete recovery (Fig. 4).

\section{CONCLUSION}

In this study, we have investigated the effect of nanostructure materials $(\mathrm{Ag}, \mathrm{Au}$ and $\mathrm{Pt}$ ) with different sharp and size to $\mathrm{NH}_{3}$ adsorption of hybrids between rGO (reduced graphene oxide) and these metals. The metal nanostructure materials play the role of bridges connecting together many rGO islands so that their contact resistance is reduced, resulting in strainght forward absorption and desorption signals. With addition of one-dimensional nanostructure (AgNWs), the enhancement of $\mathrm{NH}_{3}$ gas sensitivity of rGO-AgNWs hybrid is the highest and in particular its recovery ability is the most efficient in comparison with rGO-NPs, rGOAuNPs and PtNPs hybrids. We suggest that the work reported here is a significant step toward the practical application of rGO-based chemical sensors.

Acknowledgments: This research is funded by Vietnam National University Ho Chi Minh City (VNU-HCM) under grant number C201518-03. 


\section{Cải tiến độ nhạy khí $\mathrm{NH}_{3}$ của màng graphene oxide đã được khử bằng cách sử dụng các vật liệu kim loại có kích thước nanomet}

- Huỳnh Trần Mỹ Hòa

- Hoàng Thị Thu

- Nguyễn Thị Phương Thanh

- Nguyễn Ngọc Thắm

- Bùi Thị Tuyết Nhung

- Ôn Thị Thanh Trang

- Trần Quang Trung

Trường Đại học Khoa học Tự nhiên, ĐHQG-HCM

- Lâm Minh Long

Trường Cao đẳng nghề Kỹ thuật Công nghệ $\mathrm{Tp}$. $\mathrm{HCM}$

Trường Đại học Công nghệ, ĐHQG Hà Nội.

\section{TÓM TÁT}

Cảm biến khí là một trong những ứng dụng hứa hẹn nhất của vật liệu graphene oxide đã được khử (rGO). Tỷ lệ diện tích bề mặt/thể tích cao kết hợp với các nhóm chức chứa oxi hoạt động mạnh còn lại trên bề mặt màng rGO đã tạo nên khả năng nhạy khí tốt với các phân tử của bề mặt vật liệu rGO. Sự hồi đáp của các cảm biến chế tạo từ rGO có thể được cải thiện hơn nữa bởi sự chức năng hóa bề mặt của chúng với các vật liệu nano kim loại. Trong bài báo này, chúng tôi báo cáo hoạt động nhạy khí amoniac $\left(\mathrm{NH}_{3}\right)$ của cảm biến dựa trên rGO đã được chức hóa với ba kim loại: bạc (Ag), bạch kim (Pt) và vàng $(A u)$ trong môi trường không khí ở nhiệt độ phòng và áp suất khí quyển. Các mẫu khí được phát hiện khí bằng quan sát những thay đổi của điện trở của các tổ hợp lai rGO/kim loại khi tương tác với các phân tử khí. So với vật liệu rGO thuần, độ nhạy khí $\mathrm{NH}_{3}$ của các tổ hợp đã được tăng cường đáng kể khi bổ sung thêm các kim loại có kích thước nanomet. Các kim loại nanomet được cung cấp đóng vai trò là các cầu nối nhỏ nhằm mong muốn kết nối các mảng graphene với nhau để cải thiện các tính chất điện của tổ hợp, trong khi đó vẫn giữ được các ưu điểm vốn có của rGO khi xét về khả năng nhạy khí $\mathrm{NH}_{3}$.

Key word: Graphene oxide được khử, sợi nano Ag, phương pháp polyol, nhạy khí $\mathrm{NH}_{3}$.

\section{REFERENCES}

[1]. S. Prezioso, F. Perrozzi, L. Giancaterini, C. Cantalini, E. Treossi, V. Palermo, M. Nardone, S. Santucci and L. Ottaviano, Graphene oxide as a practical solution to

high sensitivity gas sensing, J. Phys. Chem. C. 117, 10683-10690 (2013).

[2]. G. Lu, L. E. Ocola and J. Chen, Reduced graphene oxide for room-temperature gas

Trang 76 
sensors, Nanotechnology. 20, 445502 (2009).

[3]. G. Lu, S. Park, K. Yu, R. S. Ruoff, L. E. Ocola, D. Rosenmann, J. Chen, Toward practical gas sensing with highly reduced graphene oxide: a new signal processing method to circumvent run-to-run and deviceto-device variations, American Chemical Society, 5, 2, 1154-1164 (2011).

[4]. M. Gautam, A.H. Jayatissa, Adsorption kinetics of ammonia sensing by graphene films decorated with platinum nanoparticles, Journal of Applied Physics. 111, 094317 (2012).

[5]. B.H. Chu, J. Nicolosi, C.F. Lo, W. Strupinski, S. J. Pearton, F. Ren, Effect of coated platinum thickness on hydrogen detection sensitivity of graphene-based sensors, Electrochemical and Solid-State Letters. 14, K43-K45 (2011).

[6]. Q.T. Tran, H.T.M. Hoa, D.H. Yoo, T.V. Cuong, S.H. Hur, J.S. Chung, E.J. Kim, P.A. Kohl, Reduced graphene oxide as an overcoating layer on silver nanostructures for detecting $\mathrm{NH}_{3}$ gas at room temperature, Sensors and Actuators B. 194, 45- 50 (2014).

[7]. S. Coskun, B. Aksoy and H. E. Unalan, Polyol synthesis of silver nanowires: an extensive parametric study, Cryst. Growth Des. 11, 4963-4969 (2011).

[8]. S. Köppl, Seed-mediated synthesis of high aspect ratio nanorods and nanowires of gold and silver, A dissertation submitted to ETH ZURICH, Technische Universität München (2011).

[9]. J. Chen, T. Herricks, M. Geissler, Y. Xia, Single-crystal nanowires of platinum can be synthesized by controlling the reaction rate of a polyol process, J. AM. Chem. Soc., 126, 10854-10855 (2004).

[10].T.Q. Trung, H.T.M. Hoa, N.N. Dinh, Prepare graphene by chemical method - a rapid and efficient way, Adv. Photon. Appl., 6, 334, (2010).

[11].T.Q. Trung, L.T. Lua, T.V. Tam, N.T.P. Thanh, H.T. Phong, H.T.M. Hoa, The effect of annealing temperature on conductivity of reduced graphene oxide prepared by the modified hummers method, Vietnamese J. Sci. Technol., 50, 1B, 425-431 ( 2012).

[12].Q.T. Tran, T.M.H. Huynh, D.T. Tong, V.T. Tran, N.D. Nguyen, Synthesis and application of graphene-silver nanowires composite for ammonia gas sensing, $A d v$. Nat. Sci.: Nanosci. Nanotechnol. 4, 045012 (2013).

[13].M. Zhang, Z. Wang, Nanostructured silver nanowires-graphene hybrids for enhanced electrochemical detection of hydrogen peroxide, Applied Physics Letters. 102, 213104 (2013).

[14].Y. Sun, B. Gates, B. Mayers, Y. Xia, Crystalline silver nanowires by soft solution processing, Nano Lett. 2, 2, 165 (2002).

[15].J.J. Zhu, C.X. Kan, J.G. Wan, M. Han, G.H. Wang, High-yield synthesis of uniform Ag nanowires with high aspect ratios by introducing the long-chain PVP in an improved polyol process, Journal of Nanomaterials, Article ID 982547 (2011).

[16].N.T. Khoa, S.W. Kim, D. Yoo, E.J. Kim and S.H. Hahn, Size-dependent work function and catalytic performance of gold nanoparticles decorated graphene oxide sheets, Applied Catalysis A: General. 469, 159-164 (2014). 